\title{
The right eye abducens nerve palsy as a cranial neuropathy of dengue fever: The benefit of corticosteroids in an unusual dengue sequela
}

Mohd Khairul Bin Abd Majid, Umi Kalthum Md Noh, Safinaz Md Khialdin

Department of Ophthalmology, Universiti Kebangsaan Malaysia Medical Centre (UKMMC), Jalan Yaacob Latif, Kuala Lumpur, Malaysia

\section{Abstract}

Dengue fever is very common in tropical climate countries and the number of reported cases in Malaysia shows an increasing trend recently, according to the Malaysian Clinical Practice Guidelines. Although dengue fever is common, cranial nerve mononeuropathy is a very rare manifestation in relation to other neurological-associated syndromes. We report a rare case of cranial mononeuropathy of dengue fever in Malaysia and highlight the option of steroid usage as an alternative treatment to hasten the neurological recovery. The patient, a 25-year-old healthy policeman, presented with symptomatic viral fever, which was serologically confirmed as dengue fever. He developed acute-onset binocular diplopia, which was secondary to right eye isolated abducens nerve palsy during the critical phase of dengue fever. His visual acuity was $6 / 6$ in both eyes with slightly restricted abduction of the right eye, consistent with right abducens nerve palsy, which was confirmed with a Hess test. There was corresponding diplopia over the right paracentral visual field. Urgent contrasted brain imaging was done, which ruled out the life-threatening intracranial pathology; therefore, a diagnosis of possible subclinical inflammatory changes causing sixth nerve palsy was made. Subsequently, he was treated with intravenous methylprednisolone $500 \mathrm{mg}$ daily for 3 days and regained full extraocular muscle movement after 1 week. Oral steroid was not initiated. In conclusion, although the isolated unilateral cranial mononeurop-

Correspondence: Mohd Khairul Bin Abd Majid, Department of Ophthalmology, University Kebangsaan Malaysia Medical Centre (UKMMC), Jalan Yaacob Latif, Bandar Tun Razak, 56000 Cheras, Kuala Lumpur, Malaysia.

E-mail:kerol_mkm@yahoo.com 
athy may improve spontaneously within a certain period of time, a short course of systemic corticosteroids may be considered to hasten the recovery, as it has a favourable outcome.

Keywords: Dengue fever, abducens nerve palsy, sixth nerve palsy

\section{Lumpuh saraf abdusen mata kanan sebagai neuropati kranial akibat demam denggi: Manfaat kortikosteroid dalam komplikasi denggi yang luar biasa}

\section{Abstrak}

Demam denggi sangat biasa to sering terjadi di negara-negara iklim tropika dan jumlah kes dilaporkan di Malaysia menunjukkan peningkatan trend baru-baru ini, mengikut Garis Panduan Amalan Klinikal Malaysia. Demam denggi adalah penyakit yang sering ditemui tetapi mononeuropati saraf kranial adalah manifestasi yang jarang berlaku dikalangan pesakit denggi jika dibandingkan dengan manifestasi neurologi yang lain. Kami melaporkan kes mononeuropati kranial pada pesakit demam denggi di Malaysia dan menonjolkan penggunaan steroid sebagai rawatan alternatif untuk mempercepatkan pemulihan saraf. Pesakit, seorang anggota polis yang sihat berusia 25 tahun, mengalami gejala demam viral, yang disahkan secara serologi sebagai demam denggi. Dia kemudiannya mengalami diplopia binokular akut, yang merupakan gejala sekunder untuk to akibat kelumpuhan lumpuh saraf abdusen mata kanan, pada fasa kritikal demam denggi. Ketajaman visual to penglihatannya $6 / 6$ pada kedua-dua mata dengan pergerakan mata yang sedikit terhad, konsisten dengan lumpuh saraf abdusen mata kanan, yang telah disahkan dengan ujian Hess. Terdapat diplopia yang sama di atas bidang visual paracentral to parasentral. Imbasan otak menggunakan kontras yang dilakukan secara kecemasan menolak kemungkinan terdapat patologi intrakranial yang mengancam nyawa. Diagnosis kelumpuhan saraf keenam disebabkan keradangan secara subklinikal telah dibuat. Seterusnya, ia dirawat dengan metilprednisolon intravena $500 \mathrm{mg}$ setiap hari selama 3 hari dan pemulihan sepenuhnya pergerakan otot ekstraokular diperolehi selepas 1 minggu. Steroid oral tidak dimulakan. Kesimpulannya, walaupun mononeuropati kranial unilateral adalah kes terpencil tetapi boleh berlaku secara spontan dalam tempoh tertentu, kortikosteroid sistemik pada jangka pendek mungkin dipertimbangkan untuk mempercepatkan pemulihan, kerana ia menunjukkan hasil yangmemuaskan. 
Kata kunci: Demam denggi, lumpuh saraf abdusens, lumpuh saraf kranial keenam

\section{Introduction}

Dengue fever is very common in tropical climate countries including Malaysia, where the number of reported dengue fever and dengue haemorrhagic fever cases shows an increasing trend recently, according to Malaysian Clinical Practice Guidelines. ${ }^{1}$ Dengue-related ocular manifestations are more confined towards posterior segment involvement, which consist of maculopathy, retinal oedema, retinal haemorrhages, optic neuropathy, and vitritis. ${ }^{2}$ Although dengue fever is common in tropical countries, cranial nerve mononeuropathy is a very rare manifestation in relation to other neurological-associated syndromes. ${ }^{3}$

Dengue-related ocular findings may cause visual disturbances, such as reduced vision, metamorphopsia, or cranial neuropathies involved in ocular muscle movements. We report a rare case of abducens nerve palsy secondary to dengue fever, which resulted in disabling diplopia. We highlight the importance of ruling out intracranial pathology and initiation of systemic corticosteroids to hasten the neurological recovery.

\section{Case Report}

A 25-year-old healthy policeman presented with a 3-day history of fever associated with maculopapular rash, vomiting, and abdominal pain. Clinically he was treated for dengue fever with warning signs, which was diagnosed in the febrile phase of dengue fever. Both dengue non-structural protein 1 (NS-1) antigen and dengue-specific immunoglobulin (IgG) results were positive. Subsequently, on day seven of the illness, he was noticed to have symptomatic acute-onset binocular diplopia associated with a slight pain on eye movement on right lateral gaze. There were no other ocular symptoms.

On examination, he had maculopapular rashes over the face, thorax, and both upper and lower limbs. Otherwise his vital signs were stable. His visual acuity was $6 / 6$ in both eyes with slightly restricted abduction of the right eye, consistent with right sixth cranial nerve palsy, confirmed with a Hess test (Fig. 1). There was corresponding diplopia over the right paracentral visual field (Fig. 2). Relative afferent pupillary defect was negative and other ocular examinations, including dilated fundus assessment, were unremarkable. His ocular investigation included optical coherence tomography of both maculae, which was normal (Fig. 3).

The initial laboratory investigations revealed haemoconcentration, with haematocrit of $46 \%$ along with low white cell $\left(2.6 \times 10^{9} / \mathrm{L}\right)$ and platelet $(219 \times$ $10^{9} / \mathrm{L}$ ) counts. His liver enzyme alanine transaminase (ALT) was elevated as high as 


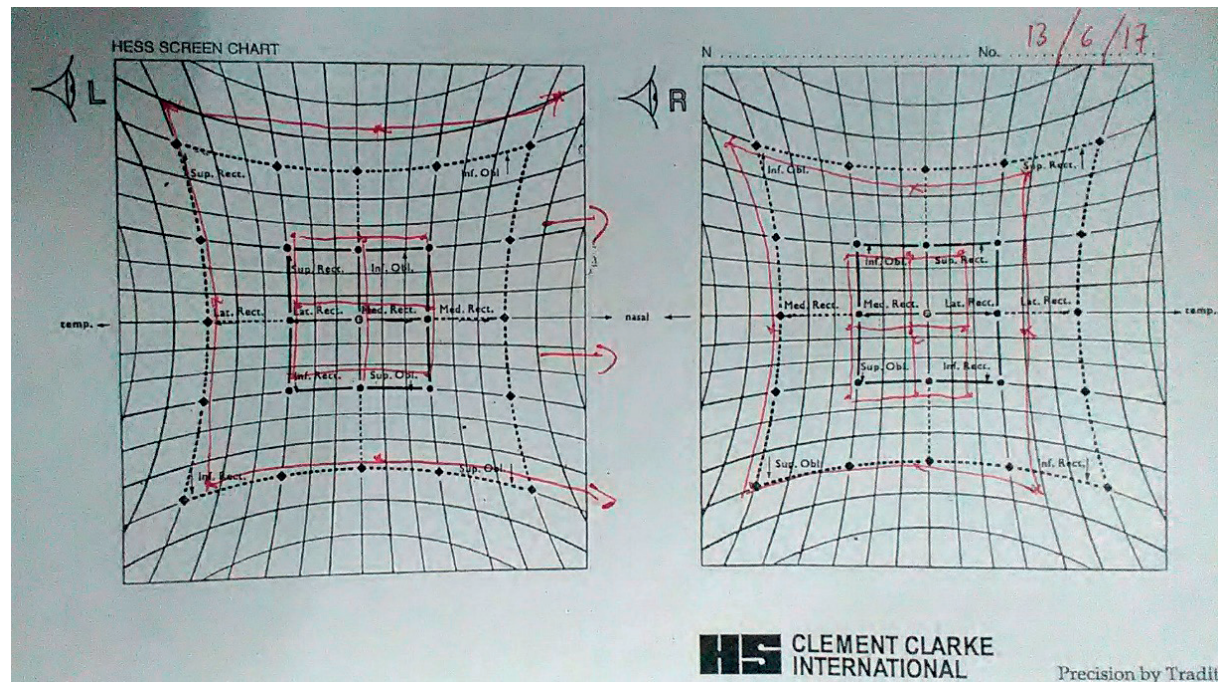

Fig. 1. Hess chart showing right lateral rectus underaction and left medial rectus overaction suggestive for right lateral rectus palsy on day seven of illness.

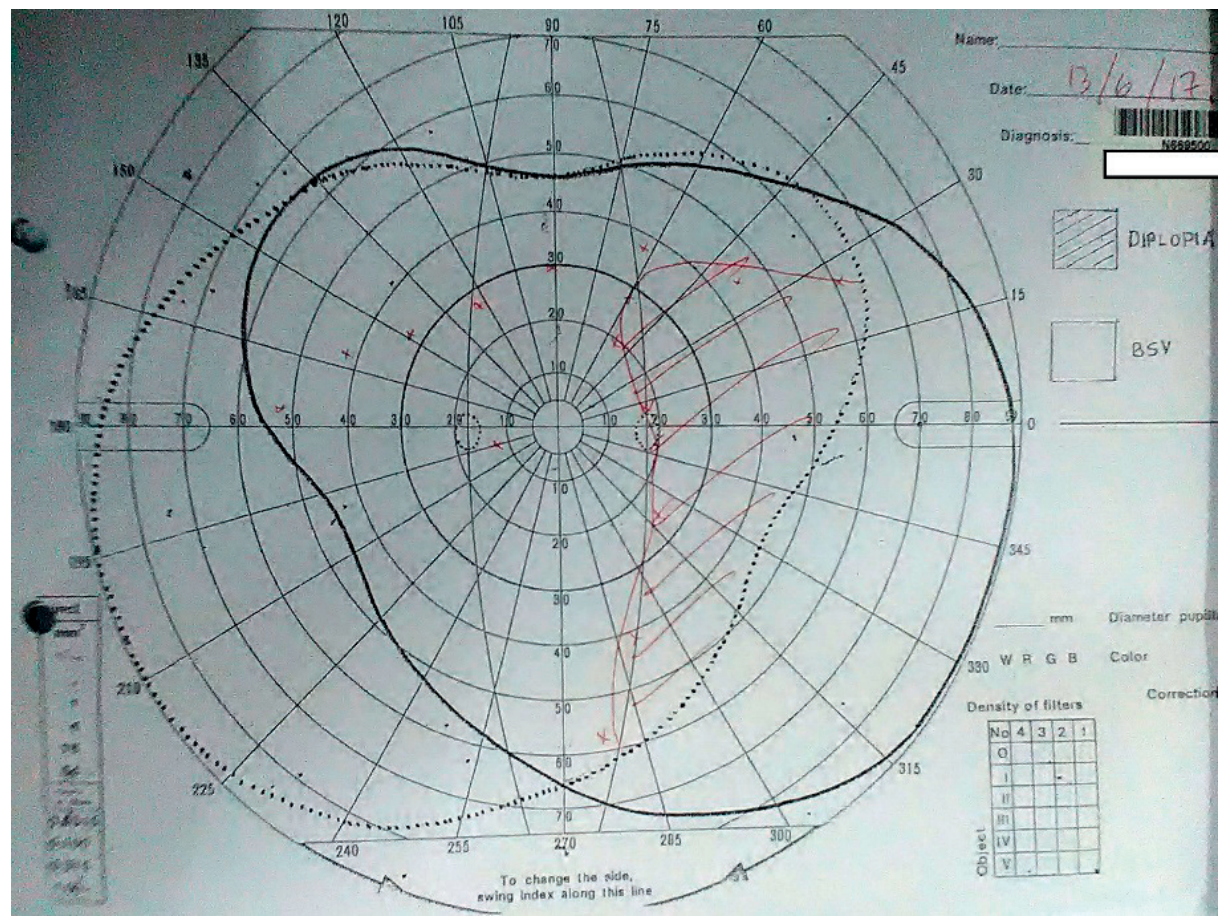

Fig. 2. Binocular single vision (BSV) showed diplopia over the right paracentral visual field. 


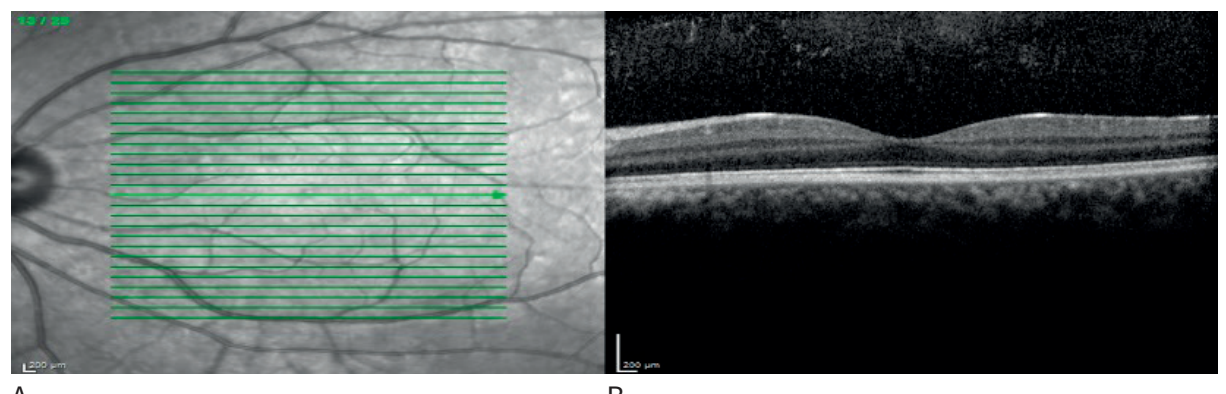

A

B

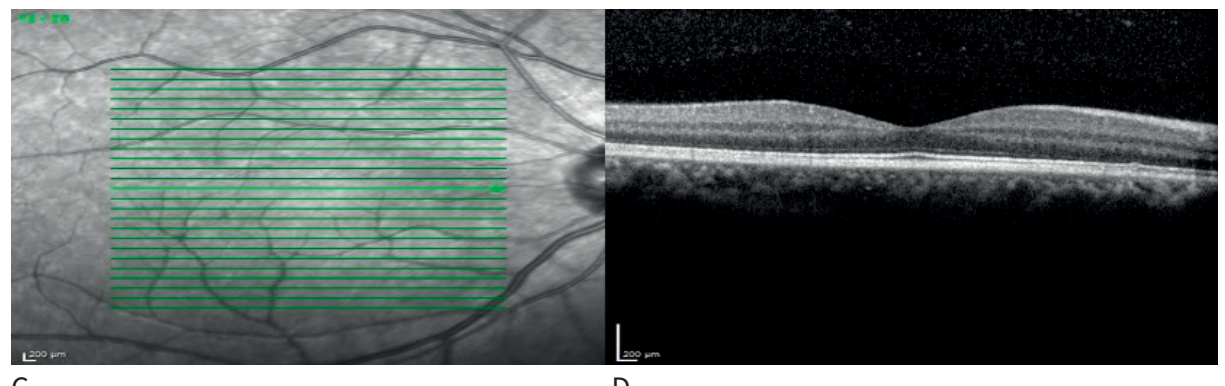

C

D

Fig. 3. Normal optical coherence tomography (OCT) of macula (OU). (A) OCT of left eye; (B) OCT macula, left eye fovea contour preserved; (C) OCT of right eye; and (D) OCT macula, right eye fovea contour preserved.

$138 \mathrm{U} / \mathrm{L}$, which indicates liver transaminitis secondary to dengue fever. His lowest white cell count was $2.6 \times 10^{9} / \mathrm{L}$ (febrile phase), his highest haematocrit was $53.3 \%$ (critical phase), and his lowest platelet count was $150 \times 10^{9} / \mathrm{L}$ (critical phase).

His renal profile and chest radiograph were normal. Contrast-enhanced computed tomography of the brain was performed to investigate the sudden development of abducens nerve palsy; the results of the test were normal.

The patient was managed by a multidisciplinary team during admission. He received initial dengue fever supportive treatment; intravenous fluid replacement was given to maintain his haemodynamic status. Pertaining to his ocular symptoms, a short course of intravenous methylprednisolone $500 \mathrm{mg}$ daily for 3 days was initiated after the febrile phase of illness, to expedite his neurological recovery. Subsequently, he was discharged with improving diplopia after completion of the intravenous methylprednisolone course, and no transition to oral steroid was given. A week later, the patient was reviewed at the eye clinic with fully resolved diplopia and full eye movement. 


\section{Discussion}

The prevalence of neurological-associated complications of dengue fever is between $0.5 \%$ and $5.4 \%$ in South East Asians. ${ }^{2}$ The incident of paralytic squint secondary to abducens nerve palsy is still rare, ${ }^{3}$ particularly in Malaysia; there has been only one case involving isolated right cranial nerve palsy, which was reported in 2016. In a previous literature review, other immune-mediated syndromes associated with dengue fever, including myelitis, acute disseminated encephalomyelitis, GuillainBarré syndrome, and myositis, have been reported. ${ }^{2}$

The exact underlying pathomechanism is still uncertain, as the dengue virus has not been isolated in the cerebrospinal fluid of affected patients. The pathogenesis of ocular manifestation of dengue fever is believed to be due to cell-mediated immunity. ${ }^{2}$ Francisco Javier et al. ${ }^{4}$ reported that post-infectious syndromes, including mononeuropathy, have been linked to immune-related neurological syndromes. Dengue virus (DENV) infection is postulated to trigger cytokine overproduction, resulting in immune-mediated endothelial dysfunction, subsequently causing demyelinating types of conduction defects.

The dengue virus-2 (DENV-2) and dengue virus-3 (DENV-3) serotypes are the virus strains commonly associated with neurological manifestation. ${ }^{2}$ Previous case reports of cranial mononeuropathy by Shivanthan et $a .^{3}{ }^{3}$ and Mazliha et al. ${ }^{5}$ do not describe any visual disturbances. Our patient presented with a sudden onset of binocular diplopia with no blurring of vision. Thus, we postulate that cranial mononeuropathy tends to occur in isolation.

Most of the reported cases that have been treated with intravenous methylprednisolone or oral prednisolone had a favourable outcome. Our patient, who was a previously healthy young man, presented with acute symptomatic binocular diplopia during the critical phase of dengue fever. Intravenous corticosteroid was initiated to expedite the recovery of the mononeuropathy. Clinically, we noticed the patient had a faster response and recovered early, which was comparable to previously reported cases by Shivanthan et al. ${ }^{3}$ and Mazliha et al. ${ }^{5}$ their case reports showed symptoms only recovered after one and three months, respectively, without any steroid commencement. Even though the corticosteroid could reduce the underlying inflammatory process, we were not able to determine the exact factors that contributed to the response.

The prognosis for cranial mononeuropathy due to dengue fever is good, both if treated conservatively or by intravenous corticosteroid. Kristine et al. ${ }^{6}$ concluded that the usage of steroids to expedite the recovery, as well as to prevent further structural damage, could justify the treatment choice unless it is contraindicated. It is important to be cautious when using high doses of steroids in acute viraemia in the febrile phase of dengue haemorrhagic fever and dengue shock syndrome, due to the possible risk of worsening of the dengue illness. This is because there is the possibility of a rise in viral replication as a result of the immunosuppressive 
properties of steroids. ${ }^{7}$ In our reported case, the intravenous corticosteroid was only initiated after the febrile phase of the illness with no other clinical contraindication, as to balance the benefit of the outcome.

In conclusion, isolated unilateral cranial mononeuropathy may improve spontaneously within a certain period of time. Monitoring of the disease activity is mandatory, with an option of systemic corticosteroid to be considered, as it has a favourable outcome.

\section{References}

1. Clinical practice guidelines: Management of dengue infection in adults. 3rd ed. Putrajaya, Malaysia: Malaysia Health Technology Assessment Section; 2015.

2. Carod-Artal FJ, Wichmann O, Farrar J, Gascón J. Neurological complications of dengue virus infection. Lancet Neurol. 2013;12(9):906-919.

3. Shivanthan MC, Ratnayake EC, Wijesiriwardena BC, Somaratna KC, Gamagedara LK. Paralytic squint due to abducens nerve palsy: a rare consequence of dengue fever. BMC Infect Dis. 2012;12:156.

4. Carod-Artal FJ. Neurological manifestations of dengue viral infection. Res Rep Trop Med. 2014;5:95104.

5. Mazliha M, Boo YL, Chin PW. Isolated unilateral sixth cranial nerve palsy: A rare presentation of dengue fever. Malays Fam Physician. 2016;11(1);25-26.

6. Bacsal KE, Chee SP, Cheng CL, Flores JV. Dengue-associated maculopathy. Arch Ophthalmol. 2007;125(4):501-510.

7. Kularatne SA, Walathara C, Mahindawansa SI, et al. Efficacy of low dose dexamethasone in severe thrombocytopenia caused by dengue fever: a placebo controlled study. Postgrad Med J. 2009;85(1008):525-529. 